\title{
A tribute to the Midlands Centre for Spinal Injuries with the help of princes, pioneers and poets
}

'Then we set out for Whitchurch and Oswestry. As we entered their territory, we were met by the Princes of Powys ... and others .. . we spent the night at Oswestry, that is the tree of Saint Oswald . . . we were entertained most splendidly and sumptuously in the English fashion by William Fitz Alan, a hospitable young nobleman .... ${ }^{1}$ This is how Gerald of Wales, a priest and historian who accompanied Baldwin, Archbishop of Canterbury on his travels through Britain in 1188 , described a visit to Oswestry. In Spinal Injuries, Oswestry is best known for its Robert Jones and Agnes Hunt Orthopaedic Hospital, which presently celebrates the centenary of its foundation. ${ }^{2-5}$ This hospital, unlike so many others, does not bear the name of a religious or royal patron, but commemorates two outstanding medical personalities who shaped its development.

Agnes Hunt was a lady from Shropshire who, despite being disabled by arthritis of the hip since childhood, became a nurse. In 1900, with the help of family and friends, she opened a small sanatorium for sick and disabled children, the Baschurch Home, which grew very quickly. Since many of her young patients needed operations, she enlisted the help of Robert Jones, a Liverpool surgeon, whose fight to establish orthopaedics as a fully-fledged branch of medicine would eventually earn him the title of 'Father of Orthopaedics'. The 'Baschurch Home' moved to Oswestry in 1920 and became an orthopaedic hospital. In 1921 the newborn British Orthopaedic Association held its meeting at the hospital, presided by Robert Jones. He died in 1933 and shortly afterwards the Board of Management renamed the institution The Robert Jones and Agnes Hunt Orthopaedic Hospital. To our friends there, and especially to those at the Midlands Centre for Spinal Injuries, on the occasion of the inauguration of their new centre, we dedicate this miniature historical guide through their region. History lurches in many corners of this green, bucolic province, which, through some of its more famous sons, has unexpected connections to far away places.

As Gerald of Wales mentioned, the town of Oswestry is said to owe its name to the contraction of the words Oswald's Tree; a reminder of some rather bloody events in the 7th century involving AngloSaxon King Oswald.

Oswald was born around 605, one of the sons of King Aethelfrith of Northumbria. When Oswald was 17 his father was killed and succeeded by his own brother in law, King Edwin. Oswald fled to the island of Iona in the Hebrides and found refuge in a monastic settlement where he became a Christian.

In 634, several battles and killings later, Oswald succeeded Edwin as king of Northumbria and ruled over a large part of Britain. In 641 transfer of power occurred in the usual fashion when King Oswald was defeated and slain by King Penda of Mercia at the battle of Maserfeld, which then became Oswald's Tree, Oswestry. ${ }^{6}$ Things eventually calmed down and times became less 'troublous', as they used to say.

Not far from Oswestry lies the town of Wrexham, with its Church of St. Giles (who used to be the patron saint of the cripples, before they became the disabled). A replica of this church stands on the campus of Yale University in New Haven, Connecticut. It appears 'Yale' is the anglicized version of the Welsh family name 'Plas yn Ial'. A Welsh pioneer couple by that name left England for America in 1638 and was among the founders of New Haven. Their son Elihu Yale was born in Boston, Massachusetts, in 1649. Three years later the family returned to London, where Elihu grew up, received his education and survived both the plague and the Great Fire. $\mathrm{He}$ joined the English East Indian Company, for which he travelled extensively, eventually settling in Madras, India, as governor of Fort St. George, where he married one Catherine in 1680.

Life at the Fort must have been very busy for Elihu: 'It is regrettable to have to admit, in light of historical evidence (. . .), that he also was living during his residence at Madras, in immoral relations with Mrs. Micks and a Mrs. Pavia, the latter a Portuguese Jewess, at his garden house in Fort George'? ${ }^{7}$ In 1699 Yale returned to England with his family. He built a house in London but spent most of his time in Wales. His name appears in the parish books of Wrexham, where he made a big donation to St. Giles' Church in 1707.

In 1711 the London representative for the Colony of Connecticut contacted Elihu Yale and asked for his contribution to an institution of higher learning in the Colony. Yale responded with a cargo of gifts including books, and East India goods which were sold to profit the school. This donation was honoured by naming the college Yale. $^{8}$

Elihu was buried outside St. Giles' Church in Wrexham with this epitaph:

'Born in America, in Europe bred, In Africa travell'd, and in Asia wed, Where long he lov'd and thriv'd, 
In London dead. Much good, some ill, he did;

So hope all's even,

And that his soul thro' mercy's gone to heaven.'

Digitalis, the drug made from the dried leaves of the flower called common foxglove, is known to every physician, but very few know that its medical use is linked to Shropshire: once upon a time there was an old lady in Shropshire (whose name History has not preserved). She must have been very good with herbal remedies and she had her own secret formulas for them. Around 1775 she told William Withering of Birmingham that 'foxglove is good for dropsy'.

Withering $(1741-1799)$ was one of the ablest clinicians of his time. He had studied medicine in Edinburgh before working in Birmingham and his many subjects of interest included scarlet fever, tuberculosis, mineral waters, climatology and music. Withering recognized digitalis as the active ingredient in the old lady's secret formula and advocated its use as a diuretic. He tried it successfully on patients with heart problems. Since he was also a great botanist, he was hailed as the 'flower of physicians'. ${ }^{10}$

Shrewsbury's most famous son is Charles Darwin, who was born there in 1809, the child of Robert Darwin, a well known physician in that town, and the grandson of Erasmus Darwin, a prominent scientist, physician and poet. His other grandfather was even better known: Josiah Wedgwood, the pioneer of English porcelain and a leader of the Industrial Revolution. Charles went to school in Shrewsbury until 1825, moving on to Edinburgh and Cambridge, where he studied medicine and theology. From 1831 to 1836 he sailed on the 'Beagle' as naturalist with its surveying expedition. His observations during this voyage triggered his reflections on the modification of species. He published his revolutionary ideas on evolution in many books, the two most famous ones being On the Origin of Species by Means of Natural Selection (1859) and The Descent of Man (1871).

He had married his cousin Emma Wedgwood in 1839 , and this bit of natural selection brought together some very good genes: of their seven children, four became prominent scientists (one astronomer, one botanist, one economist and one civil engineer). ${ }^{11}$

Having thus reached the end of the 19th century, we return to Oswestry, where England's most famous anti-war poet Wilfred Owen was born in 1893 at Plas Wilmot, a house that still stands. In 1913 he went to France as an English teacher and began writing poems. Owen joined the Artist's Rifles in 1915 and was sent to the front. A few weeks in the trenches changed his outlook on life and on poetry. The brutality of war filled him with revulsion and with compassion for 'those who die as cattle'. ${ }^{12}$ In 1917 he suffered shell shock and was brought to Craiglockhart Hospital in Edinburgh, where he met the poet Siegfried Sassoon, who encouraged him to publish his poems. He returned to the front in August 1918, received the Military Cross in October and was killed just one week before the war ended, in November 1918. Owen's moving anti-war poems were published after his death by Sassoon and have grown in popularity ever since. ${ }^{13}$

To borrow Gerald of Wales' words, one could certainly say patients coming to the Midlands Centre for Spinal Injuries are medically treated 'most splendidly', although 'sumptuously' might not be an exact description of an NHS environment . . . This centre has achieved international recognition thanks to its outstanding contributions to the treatment of spinal injuries:

- The Oswestry Standing Frame ${ }^{14}$

- The Oswestry Assessment Scale for Activities of Daily Living ${ }^{15}$

- The concept of physiological instability of the spinal cord along with the bio-mechanical instability of the spinal column

- The notion that spinal canal encroachment does not necessarily forecast the neurological outcome ${ }^{16-19}$

- The creation of transitional housing (Transhouse) for severely disabled patients leaving the hospital

- A community liaison service ('case management')

- The confirmation, through new technology, of Sir Ludwig Guttmann and HL Frankel's long established views on the outcome of conservative management.

May the Midlands Centre for Spinal Injuries continue to prosper in its new centre.

\section{A Ohry \\ Sackler Faculty of Medicine, Tel Aviv University, K Ohry-Kossoy}

\section{References}

1 Gerald of Wales. The journey through Wales, the description of Wales. Penguin Classics, translated by L Thorpe, 1978

2 Watson F. The idealism of Sir Robert Jones. Bodynfoel: Llanfehain, 1934.

3 Malkin SAS. The conquest of disability. Ann Roy Coll Surg Eng 1957; 20: $99-111$.

4 Hunt A. This is my life. Printed by A Wheator, Derwen Cripples' Training College, Oswestry, 1965.

5 Watson F. The life of Sir Robert Jones. Hodder \& Stoughton, 1934.

6 On St. Oswald and Oswestry, in Oswestry, Encyclopaedia Britannica, London, 1960; 16: 960.

7 On Elihu Yale, on http://www.britannia.com/wales/7wonders wonder $2 / \mathrm{html}$ and on http://www.iconn.net/dcyale/ g0000026.html

8 Yale University, in Encyclopaedia Britannica 1960; 23: 871-872.

9 Krinkler DM. The foxglove, the old woman from Shropshire and William Withering. J Am Coll Cardiol 1985; 5 (Suppl a): 3A -9A.

10 Digitalis. Encyclopaedia Britannica 1960; 7: $382-383$.

11 Darwin C. Encyclopaedia Britannica 1960; 7: 65-67.

12 Owen W. Encyclopaedia Britannica 1960; 16: 979-980.

13 The Poems of Wilfred Owen. Chatto: London, 1999.

14 Tussler D. The Oswestry standing frame: use following spinal cord injury. Br J Ther Rehab 1998; 5: 1-3. 
15 Oswestry's Activities of Daily Living Assessment. On http:// www.healthsc.com/oswestry.htm

16 El Masri WS, Short DJ. Current concepts: spinal injuries and rehabilitation. Curr Opin Neurol 1997; 10: 484-492.

17 Katoh S, El Masri WS. Neurological recovery after conservative treatment of cervical cord injuries. J Bone Joint Surg (BR) 1994; 76B: $225-228$.
18 El Masri WS et al. Validation of the American spinal injury association motor score and the national acute spinal cord injury study motor score. Spine 1996; 21: 614-619.

19 Katoh S, El Masri WS. Motor recovery of patients presenting with motor paralysis and sensory sparing following cervical spinal cord injuries. Paraplegia 1995; 33: 506-509. 